\title{
Refinement of the crystal structure of a synthetic non-stoichiometric Rb-feldspar
}

\author{
A. KYONO* AND M. KIMATA
}

Institute of Geoscience, University of Tsukuba, Tennodai 1-1-1, Tsukuba, Ibaraki, 305-8571, Japan

\section{ABSTR ACT}

The crystal structure of hydrothermally synthesized Rb-feldspar (monoclinic, space group $C 2 / m, a=$ 8.839(2) $\left.\AA, b=13.035(2) \AA, c=7.175(2) \AA, \beta=116.11(1)^{\circ}, V=742.3(3) \AA^{3}, Z=4\right)$ has been refined to a final $R$ of 0.0574 for 692 independent X-ray reflections. Microprobe analyses of the Rb-feldspar suggest deviation from stoichiometry, with excess $\mathrm{Si}$ and $\mathrm{Al}$, resulting in a unit formula of $\mathrm{Rb}_{0.811} \square_{0.127} \mathrm{Al}_{1.059} \mathrm{Si}_{3.003} \mathrm{O}_{8}$. Infrared (IR) spectra indicate the structural occupancy of large $\mathrm{H}_{2} \mathrm{O}$ content, which implies that the $\square \mathrm{Si}_{4} \mathrm{O}_{8}$ substitution favours the structural incorporation of the $\mathrm{H}_{2} \mathrm{O}$ molecule at the $M$-site. The mean $T-\mathrm{O}$ distances are $1.632 \AA$ for $T 1$ and $1.645 \AA$ for $T 2$, revealing highly disordered $(\mathrm{Al}, \mathrm{Si})$ distribution with $\mathrm{Al} / \mathrm{Si}=0.245 / 0.755$ ( $T 1$ site) and $0.255 / 0.745$ ( $T 2$ site) .

There are two geochemical implications from this refinement: (1) identification of both rubicline triclinic with $(\mathrm{Al}, \mathrm{Si})$ ordered distribution and synthetic monoclinic $\mathrm{RbAlSi}_{3} \mathrm{O}_{8}$ with $(\mathrm{Al}, \mathrm{Si})$ disordered distribution implies that $\mathrm{Rb}$ cannot be one of factors disrupting the ( $\mathrm{Al}, \mathrm{Si}$ ) ordered and disordered distributions in feldspars; and (2) natural and synthetic feldspars capable of accommodating the large cations tend to incorporate $\square \mathrm{Si}_{4} \mathrm{O}_{8}$, excess $\mathrm{Al}$ and $\mathrm{H}_{2} \mathrm{O}$ components in their crystal structures.

KEYWORDs: Rb-feldspar, $\square \mathrm{Si}_{4} \mathrm{O}_{8}$, Al-excess substitution, $\mathrm{H}_{2} \mathrm{O}$ molecule.

\section{Introduction}

RUBICLINE, the $\mathrm{Rb}$ analogue of microcline, $(\mathrm{Rb}, \mathrm{K}) \mathrm{AlSi}_{3} \mathrm{O}_{8}$, ideally $\mathrm{RbAlSi}_{3} \mathrm{O}_{8}$, occurs in several kinds of granitic pegmatites (Teertstra et al., 1997, 1998b, 1999a). The chemical analyses by electron microprobe show that the 'excess-Si' $\square \mathrm{Si}_{4} \mathrm{O}_{8}$ component is normally incorporated into rubiclines, where the maximum limit of solubility is $\sim 5 \mathrm{~mol} \% \square \square \mathrm{Si}_{4} \mathrm{O}_{8}$ (Teertstra et al., 1998a). However, pure $\mathrm{RbAlSi}_{3} \mathrm{O}_{8}$ feldspar has never been discovered in nature (e.g. $91 \mathrm{~mol} \%$ in Teertstra et al., 1997; $73 \mathrm{~mol} \%$ in Teertstra et al., 1998b, etc.), and it is not known whether the chemical compositions of Rb-feldspars previously synthesized (e.g. Gasperin, 1971; Voncken et al., 1993) have a stoichiometric $\mathrm{RbAlSi}_{3} \mathrm{O}_{8}$ composition.

Synthetic Rb-feldspars were grouped topologically into two kinds: (1) the monoclinic structures

* E-mail: kyono@esca.geo.tsukuba.ac.jp with space group $C 2 / m$ comparable to sanidine (Barrer and McCallum, 1953; Ghélis and Gasperin, 1970; Gasperin, 1971; Pentinghaus and Bambauer, 1971; Bruno and Pentinghaus, 1974; Voncken et al., 1993; Koval'skii et al., 2000); and (2) the triclinic structure with space group $C \overline{1}$ analogues to low-microcline (Wietze and Wiswanathan, 1971; Grove and Ito, 1973; McMillan et al., 1980). The crystal structure of monoclinic synthetic $\mathrm{RbAlSi}_{3} \mathrm{O}_{8}$ feldspar was refined to $R=0.07$ using only the isotopic temperature factor (Gasperin, 1971), but the chemical composition was not checked. Therefore, one of the major problems in $\mathrm{Rb}$-feldspar concerns the relationship between the variation in space group due to $(\mathrm{Al}, \mathrm{Si})$ ordering and the solubility of the 'excess-Si' $\square \mathrm{Si}_{4} \mathrm{O}_{8}$ substitution.

In the present work, we report the refinement of a crystal structure of synthetic non-stoichiometric $\mathrm{Rb}$-feldspar, and discuss the relationship between the structure and deviation from stoichiometry. 


\section{A. KYONO AND M. KIMATA}

\section{Experimental}

Synthesis

Crystals of $\mathrm{Rb}$-feldspar were prepared hydrothermally using the isothermal temperature method. The precursor, a powdered natural albite $\left(\mathrm{Ab}_{98.8} \mathrm{An}_{1.0}\right)$ from Minas Gerais, Brazil, was placed in a solvent of $\mathrm{RbCl}$, of which the weight ratio to starting mineral was 20:1. The resulting mixture was inserted into a silver tube containing $\mathrm{H}_{2} \mathrm{O}$ up to a filling level of approximately $50 \%$. This tube was sealed and then placed in an autoclave, held at $400^{\circ} \mathrm{C}$ and an external pressure of $60 \mathrm{MPa}$. The largest crystals obtained, $\sim 0.1-0.3 \mathrm{~mm}$ long, were produced after a run duration of $7 \mathrm{~d}$. The product was a single phase

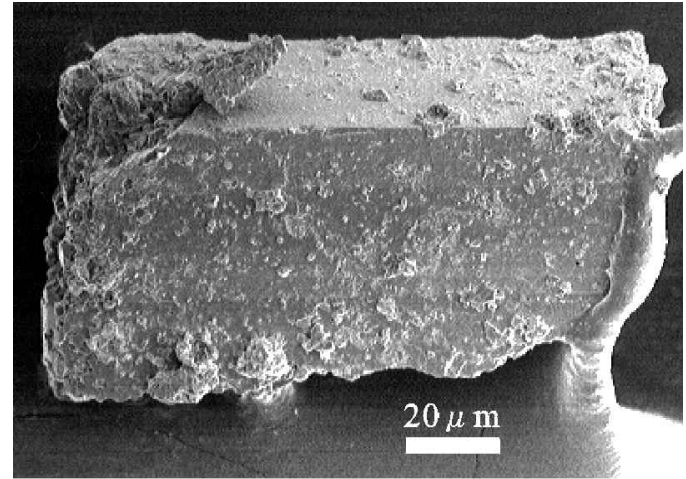

FIG. 1. SEM photograph of a synthetic Rb-feldspar.

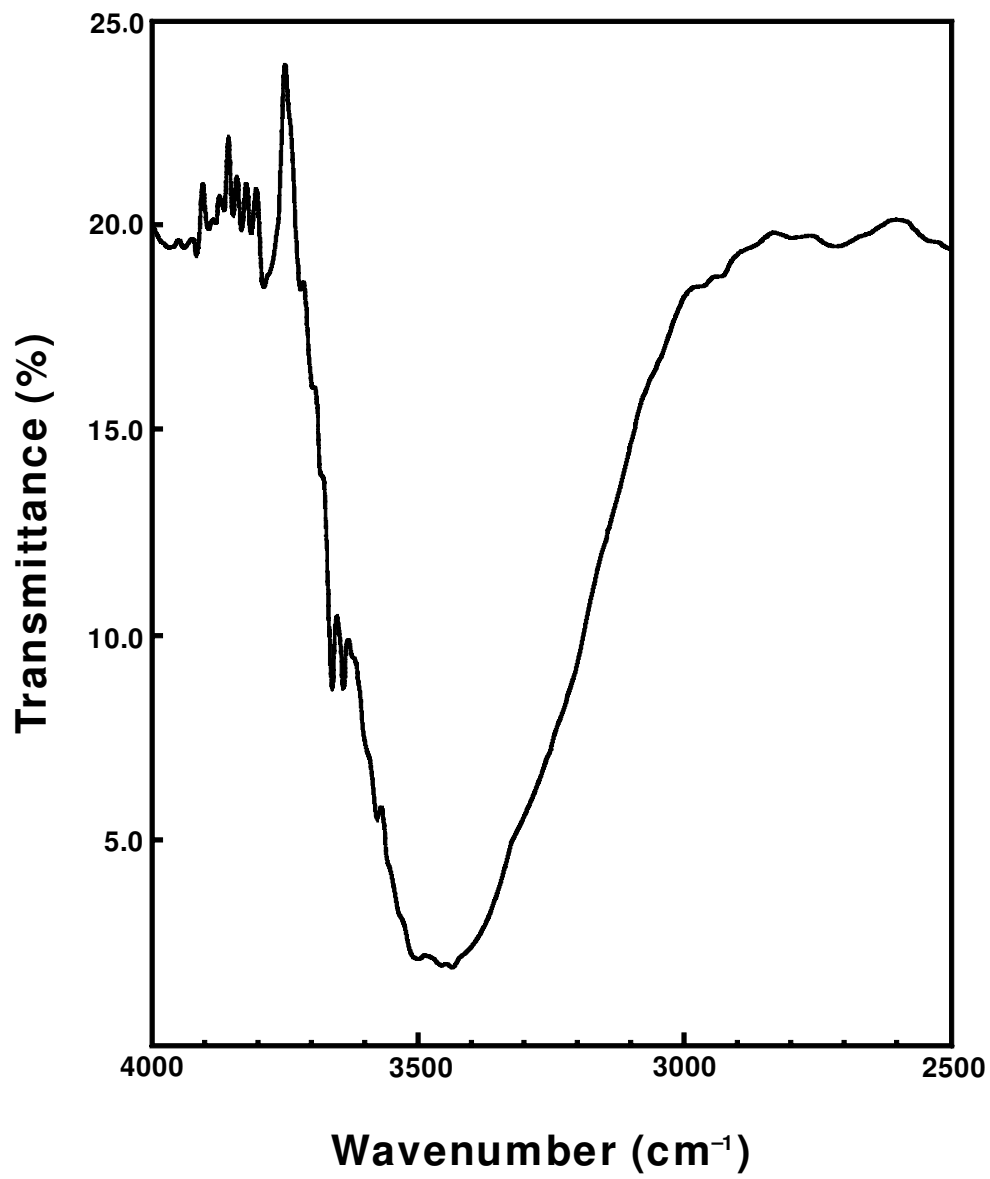

FIG. 2. IR spectrum of synthetic Rb-feldspar. 
and of high optical quality, albeit often twinned. The crystals were short prismatic and multifaceted with numerous small pores on the surface (Fig. 1).

\section{Infrared technique}

Prior to conducting IR spectroscopy, the samples were heated in an oven at $110^{\circ} \mathrm{C}$ for $12 \mathrm{~h}$ to eliminate $\mathrm{H}_{2} \mathrm{O}$ absorbed from atmospheric humidity. Single-crystal IR spectra were obtained using micro-FTIR spectroscopy (Janssen MFT2000, JASCO) over the range 4000-2500 $\mathrm{cm}^{-1}$ (Fig. 2). Averaged scans were 300 at a nominal resolution of $4 \mathrm{~cm}^{-1}$. The sample was put on the $\mathrm{KBr}$ plate with a thickness of $100 \mu \mathrm{m}$. The instrument was equipped with a Ge-coated $\mathrm{KBr}$ beamsplitter and an MCT detector. The spot size of the beam was $\sim 50 \times 50 \mu \mathrm{m}$. Measurements were made in air at room temperature.

\section{Chemical analysis}

The compositions of the crystals obtained were determined by electron microprobe techniques (JEOL superprobe JXA-8621) at the Chemical Analysis Center, University of Tsukuba, using wavelength dispersion spectroscopy (WDS). The analytical conditions were constrained at a $20 \mathrm{kV}$ accelerating voltage and a $10 \mathrm{nA}$ beam current, using a beam size of $10 \mu \mathrm{m}$. Major elements $(\mathrm{Rb}$, $\mathrm{Na}, \mathrm{Al}, \mathrm{Si}$ ) were measured using the synthetic $\mathrm{Rb}_{2} \mathrm{ZnSi}_{5} \mathrm{O}_{12}$ glass (Rb-L $\left.\alpha_{1}\right)$ (Kohn et al., 1994), with albite $\left(\mathrm{Na}-K \alpha_{1}\right)$, corundum $\left(\mathrm{Al}-K \alpha_{1}\right)$ and quartz $\left(\mathrm{Si}-K \alpha_{1}\right)$ as standards. The elements $\mathrm{K}, \mathrm{Ca}$, $\mathrm{Sr}, \mathrm{Cs}, \mathrm{Ba}, \mathrm{Pb}, \mathrm{Mn}, \mathrm{Mg}, \mathrm{Fe}, \mathrm{Ga}, \mathrm{Ti}, \mathrm{Ni}, \mathrm{P}$ and $\mathrm{F}$ were sought, but not detected. Ten analyses obtained along a line from one edge of the crystal to the other are given in Table 1 .

\section{X-ray data}

The selected crystal exhibited sharp extinction and did not show twinning. Data were collected at the Chemical Analysis Center, University of Tsukuba. The crystal was mounted on an EnrafNonius CAD-4 diffractometer, using graphitemonochromatized Mo- $K \alpha \mathrm{X}$-radiation and frame widths of $0.3^{\circ}$ in $\omega$, with 60 s spent counting per frame. More than a hemisphere of three-dimensional data was collected within the range of $2^{\circ} \leqslant 2 \theta \leqslant 70^{\circ}$ in $\sim 72 \mathrm{~h}$. The final unit-cell dimensions were refined on the basis of 25 reflections below $20^{\circ} 2 \theta$ using least-squares techniques. Comparison between the intensities of equivalent reflections during the data collection showed no evidence of significant decay. The three-dimensional data were integrated and corrected for Lorentz, polarization and background effects using the SDP program (EnrafNonius, 1983). An empirical absorption-correction was applied using the $\psi$-scan technique. A total of 1787 reflections was collected; merging of equivalent reflections gave 1685 unique reflections with 648 classed as observed $\left(\left|F_{\mathrm{o}}\right| \geqslant 4 \sigma_{\mathrm{F}}\right)$.

TABLE 1. Representative compositions of Rb-feldspar.

\begin{tabular}{|c|c|c|c|c|c|c|c|c|c|c|c|}
\hline & 1 & 2 & 3 & 4 & 5 & 6 & 7 & 8 & 9 & 10 & Average \\
\hline $\mathrm{SiO}_{2}$ & 57.67 & 59.40 & 55.12 & 56.93 & 55.22 & 58.92 & 54.69 & 56.75 & 58.03 & 53.87 & $56.66 \quad(1.58)$ \\
\hline $\mathrm{Al}_{2} \mathrm{O}_{3}$ & 17.42 & 17.00 & 16.73 & 17.54 & 17.24 & 18.13 & 15.78 & 16.67 & 16.96 & 16.03 & $16.95 \quad(0.21)$ \\
\hline $\mathrm{Rb}_{2} \mathrm{O}$ & 23.82 & 23.42 & 23.73 & 25.32 & 22.95 & 23.47 & 23.93 & 24.10 & 24.03 & 22.93 & $23.77 \quad(0.20)$ \\
\hline Sum wt. $\%$ & 98.91 & 99.82 & 95.58 & 99.79 & 95.41 & 100.52 & 94.40 & 97.52 & 99.02 & 92.83 & $97.38 \quad(3.16)$ \\
\hline \multicolumn{12}{|c|}{ Atomic compositions (a.p.f.u.) normalized to 8 oxygen atoms } \\
\hline $\mathrm{Si}$ & 3.000 & 3.039 & 2.992 & 2.976 & 2.979 & 2.994 & 3.018 & 3.012 & 3.019 & 3.004 & $3.003(0.001)$ \\
\hline $\mathrm{Al}$ & 1.068 & 1.025 & 1.069 & 1.081 & 1.096 & 1.086 & 1.026 & 1.043 & 1.0 & 1.054 & $1.059(0.001)$ \\
\hline $\mathrm{Rb}$ & 0.797 & 0.770 & 0.827 & 0.851 & 0.796 & 0.767 & 0.849 & 0.822 & 0.807 & 0.822 & $0.811(0.001)$ \\
\hline sum & 4.865 & 4.834 & 4.888 & 4.908 & 4.871 & 4.847 & 4.893 & 4.877 & 4.866 & 4.880 & $4.873(0.001)$ \\
\hline$i+A$ & & & & & & & & & & 4.0 & $4.062(0.000)$ \\
\hline$\sum$ charges & 16.001 & 16.001 & 16.002 & 15.998 & 16.000 & 16.001 & 15.999 & 15.999 & 16.003 & 16.000 & $16.000(0.000)$ \\
\hline $\mathrm{Si} / \mathrm{Al}$ & 2.809 & 2.965 & 2.799 & 2.753 & 2.718 & 2.757 & 2.942 & 2.888 & 2.903 & 2.850 & $2.838(0.003)$ \\
\hline
\end{tabular}




\section{A. KYONO AND M. KIMATA}

\section{Structure solution and refinement}

FTIR spectra

The IR spectrum of the chosen crystal is plotted in Fig. 2. A clear absorption peak near $3450 \mathrm{~cm}^{-1}$ is due not to humidity absorbed by the sample, but to $\mathrm{O}-\mathrm{H}$ stretching of structural $\mathrm{H}_{2} \mathrm{O}$ molecules (Wilkinson and Sabine, 1973). The spectra are in good agreement with that of sanidine containing $\mathrm{H}_{2} \mathrm{O}$ molecules in wavenumber as well as in relative intensities (Beran, 1986). Since the relative intensities of these bands reflect the difference in $\mathrm{H}_{2} \mathrm{O}$ content (Ballirano et al., 1996), the strong intensities of absorption bands may indicate a high $\mathrm{H}_{2} \mathrm{O}$ content.

\section{Chemistry}

In spite of the careful qualitative analyses, $\mathrm{Na}$ was not detected in the present crystals. The WDS measurements made at ten different positions on a single crystal sample averaged $56.66 \mathrm{SiO}_{2}, 16.95$ $\mathrm{Al}_{2} \mathrm{O}_{3}, 23.77 \mathrm{Rb}_{2} \mathrm{O}$, sum 97.38 wt.\% (Table 1), in reasonable agreement with the ideal values of 55.51, 15.70 and 28.79 wt. $\%$, sum 100.00 wt. $\%$. Calculation on the basis of eight oxygen atoms per formula unit (a.p.f.u.) shows that individual values of $\mathrm{Rb}$ cations are certainly $<1.000$ a.p.f.u., while sums of the $T$-cations are obviously $>4.000$ a.p.f.u. (Table 1). But $\mathrm{Si} / \mathrm{Al}$ ratios lower than the ideal $(=3.000)$ corresponding to low $\mathrm{Rb}$ cation sums, lying along the same trend for $\mathrm{Rb}$ feldspar (e.g. Teertstra et al., 1999a), lead to adjustment of the total cation charge $(=16.000)$. These deviations from stoichiometry of $\mathrm{RbAlSi}_{3} \mathrm{O}_{8}$ suggest the possibility of nonstoichiometry for this Rb-feldspar. The high $T$-cations and low $M$-cations contents are thought to conform to the $\mathrm{KAlSi}_{3} \mathrm{O}_{8}-\mathrm{RbAlSi}_{3} \mathrm{O}_{8}$ join (Teertstra et al., 1997, 1998a,b, 1999a,b). The number of $T$-cations must be constrained to 4.000 a.p.f.u. because of unrecognizable defects in $T$-cations for the general feldspar formula (Smith and Brown, 1988). Therefore, one of the end-members in the feldspar solid solution corresponds to a $\square \mathrm{Si}_{4} \mathrm{O}_{8}$ component explaining the "excess of silica" (Grundy and Ito, 1974). Furthermore, excess Al cations are observed for all Rb-feldspars in nature (Teertstra et al., $1998 a, b, 1999 a$ ). However, the refined crystal resists quantitative analysis of its $\mathrm{H}_{2} \mathrm{O}$ content because of its irregular morphology (Fig. 1), although the solubility of hydrogen feldspar $\mathrm{HAlSi}_{3} \mathrm{O}_{8}$ (Paulus and Müller, 1988) in our IR
TABLE 2. Crystallographic parameters for Rb-feldspar.

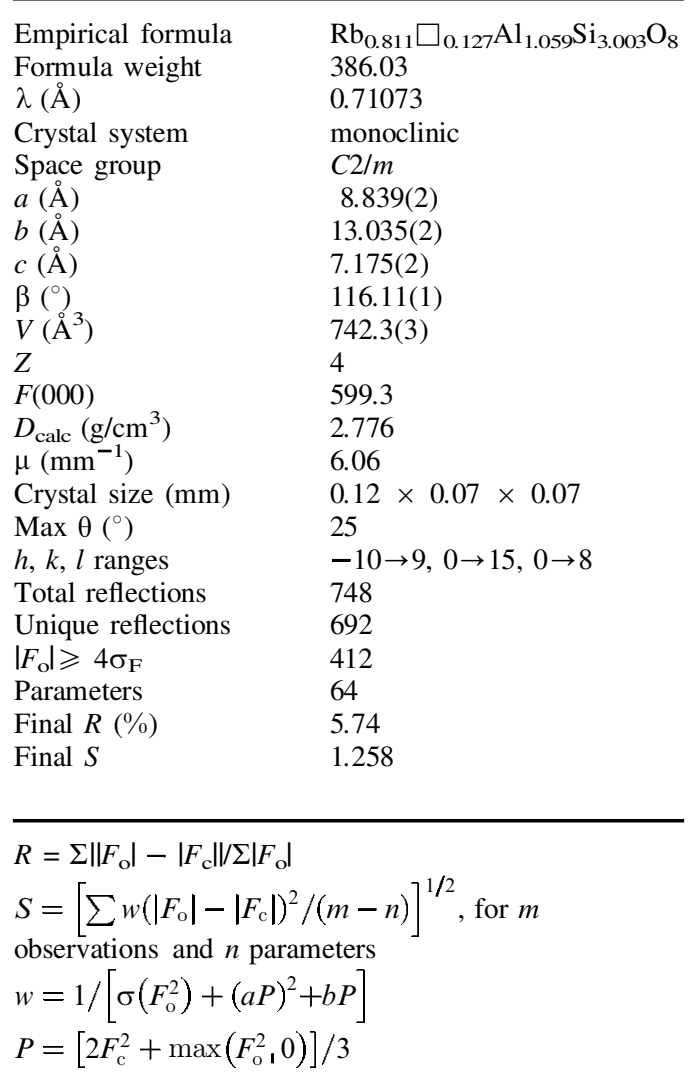

results, should be examined. In view of the fact that the phase is anhydrous, the composition of our $\mathrm{Rb}$-feldspar indicates the incorporation of an $\mathrm{Al}\left(\mathrm{Al}_{3} \mathrm{Si}\right) \mathrm{O}_{8}$ component. The final refinement was carried out adopting a scheme of solid solution towards this component. It has been suggested tentatively that as the 'excess-Al-component' the $\mathrm{Al}\left(\mathrm{Al}_{3} \mathrm{Si}\right) \mathrm{O}_{8}$ end-member is introduced into anorthite megacrysts from island arc basalts (Kimata et al., 1995). A negative correlation between Al-excess and $\mathrm{Rb}$ is shown in Fig. 3, which implies the incorporation of this Al-excess end-member. The empirical formula for the $\mathrm{Rb}$ feldspar in this study is thus estimated to be $\mathrm{Rb}_{0.811} \square_{0.127} \mathrm{Al}_{1.059} \mathrm{Si}_{3.003} \mathrm{O}_{8}$. Moreover, the $\mathrm{H}_{2} \mathrm{O}$ molecules in $\mathrm{Rb}$-feldspars have been interpreted as contributing to the processes of $(\mathrm{Al}, \mathrm{Si})$ ordering (Teertstra et al., 1998a,b). The deficiency of total wt. $\%$ in the EMP analyses (Table 1) suggests the existence of $\mathrm{H}_{2} \mathrm{O}$ in the 
TABLE 3. Atomic parameters (upper) and their estimated standard deviations (lower) for Rb-feldspar.

\begin{tabular}{lcccccccrrr}
\hline Site & $x$ & $y$ & $z$ & $U_{\text {eq }}$ & $U_{11}$ & $U_{22}$ & $U_{33}$ & $U_{23}$ & $U_{13}$ & $U_{12}\left(\AA^{2}\right)$ \\
\hline $\mathrm{Rb}$ & 0.2960 & 0.0000 & 0.1460 & 0.0454 & 0.0356 & 0.0641 & 0.0396 & 0.0000 & 0.0193 & 0.0000 \\
& 0.0004 & 0.0000 & 0.0005 & 0.0012 & 0.0017 & 0.0026 & 0.0021 & 0.0000 & 0.0015 & 0.0000 \\
$T 1$ & 0.0106 & 0.1913 & 0.2223 & 0.0474 & 0.0451 & 0.0544 & 0.0478 & -0.0008 & 0.0250 & -0.0026 \\
& 0.0007 & 0.0005 & 0.0010 & 0.0017 & 0.0032 & 0.0042 & 0.0038 & 0.0031 & 0.0030 & 0.0030 \\
$T 2$ & 0.7235 & 0.1194 & 0.3446 & 0.0492 & 0.0480 & 0.0565 & 0.0505 & 0.0030 & 0.0285 & -0.0016 \\
& 0.0007 & 0.0005 & 0.0010 & 0.0017 & 0.0035 & 0.0040 & 0.0039 & 0.0033 & 0.0031 & 0.0031 \\
OA1 & 0.0000 & 0.1557 & 0.0000 & 0.0630 & 0.0500 & 0.0745 & 0.0652 & 0.0000 & 0.0262 & 0.0000 \\
& 0.0000 & 0.0020 & 0.0000 & 0.0066 & 0.0123 & 0.0174 & 0.0159 & 0.0000 & 0.0119 & 0.0000 \\
OA2 & 0.6662 & 0.0000 & 0.2834 & 0.0490 & 0.0611 & 0.0585 & 0.0388 & 0.0000 & 0.0324 & 0.0000 \\
& 0.0026 & 0.0000 & 0.0031 & 0.0054 & 0.0130 & 0.0139 & 0.0116 & 0.0000 & 0.0105 & 0.0000 \\
OB & 0.8311 & 0.1597 & 0.2245 & 0.0645 & 0.0455 & 0.0907 & 0.0595 & -0.0036 & 0.0252 & 0.0002 \\
& 0.0018 & 0.0015 & 0.0026 & 0.0050 & 0.0084 & 0.0140 & 0.0103 & 0.0097 & 0.0077 & 0.0088 \\
OC & 0.0444 & 0.3130 & 0.2585 & 0.0646 & 0.0827 & 0.0772 & 0.0413 & -0.0004 & 0.0341 & 0.0107 \\
& 0.0022 & 0.0014 & 0.0023 & 0.0049 & 0.0110 & 0.0120 & 0.0100 & 0.0088 & 0.0087 & 0.0104 \\
OD & 0.1692 & 0.1292 & 0.4026 & 0.0560 & 0.0617 & 0.0538 & 0.0671 & 0.0002 & 0.0416 & 0.0012 \\
& 0.0020 & 0.0012 & 0.0027 & 0.0042 & 0.0092 & 0.0100 & 0.0106 & 0.0085 & 0.0085 & 0.0083 \\
& & & & & & & & & & \\
\hline
\end{tabular}

$U_{\mathrm{eq}}=1 / 3 \Sigma U_{\mathrm{ij}} a_{\mathrm{i}}^{*} b_{\mathrm{j}}^{*} a_{\mathrm{i}} b_{\mathrm{j}}$

The anisotropic displacement factors are of the form: $-2 \pi^{2}\left[h^{2} a^{*} U_{11}+\ldots \ldots \ldots \ldots+2 h k a * b U_{12}\right]$

Rb-feldspar supported by the IR spectrum data (Fig. 2).

\section{Structural refinement}

The SHELXL-97 program was used for crystal structure refinement of the Rb-feldspar. The structure was refined in the space group $C 2 / m$,

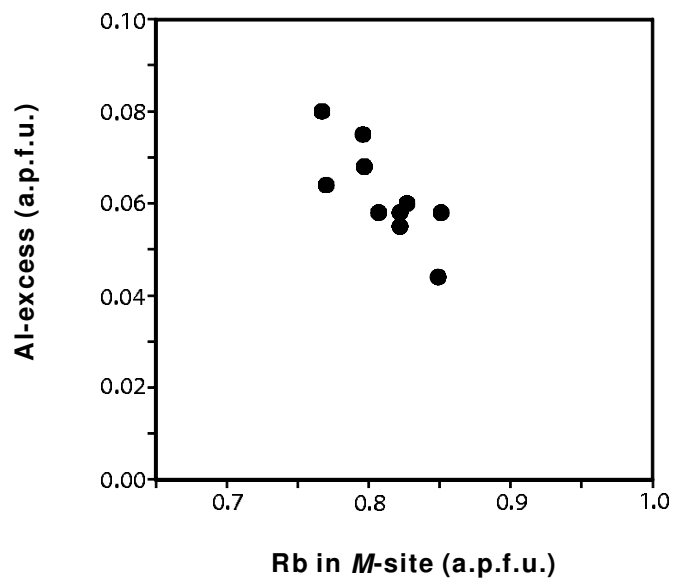

FIG. 3. Relationship between $\mathrm{Rb}$ in $M$-site and excess $\mathrm{Al}$ in synthetic Rb-feldspar. and the starting atomic coordinates were taken from the structure of $\mathrm{RbAlSi}_{3} \mathrm{O}_{8}$ (Gasperin, 1971). Conventional refinements of diffraction data yielded reasonable interatomic distances and angles for the tetrahedral framework, but an agreement index $(R)$ was very large $(\sim 10 \%)$ when all the reflections from $2-70^{\circ} 2 \theta$ were used. After omitting the reflections of higher angles $\left(2 \theta>50^{\circ}\right)$ because of the extreme weakness in these intensities, the $R$-value dropped drastically to $5.77 \%$ for $\mathrm{Rb}$-feldspar. Moreover, after refining based on the chemical composition determined by EMPA, the final $R$ factor achieved is $5.74 \%$ (Table 2), introducing the occupancies of 'excess$\mathrm{Al}^{\prime}$ at the $M$-site. Final positional and displacement parameters are given in Table 3 and selected interatomic distances and angles in Table 4.

\section{Structure description}

Examination of Fig. 4 shows that the calculated ellipsoids are not greatly distorted from spherical. Therefore no attempt was made to refine the structure using split atom positions, although no difference Fourier calculations were performed. Judging from the non-stoichiometry of the refined crystal, the final $R$-value $(5.74 \%)$ is more reliable than that reported previously $(7 \%)$ for disordered 


\section{A. KYONO AND M. KIMATA}

TABLE 4. Selected interatomic distances $(\AA)$, angles $\left(^{\circ}\right)$ and bond valences* (bv) for Rb-feldspar.

\begin{tabular}{|c|c|c|c|c|c|c|}
\hline$T 1-\mathrm{OA} 1$ & 1.624 & (10) & & $\mathrm{OA} 1-T 1-\mathrm{OB}$ & 107.4 & (8) \\
\hline$-\mathrm{OB}$ & 1.646 & (16) & & $\mathrm{OA} 1-T 1-\mathrm{OC}$ & 111.4 & (11) \\
\hline$-\mathrm{OC}$ & 1.613 & (21) & & $\mathrm{OA} 1-T 1-\mathrm{OD}$ & 107.0 & (8) \\
\hline$-O D$ & 1.643 & (17) & & $\mathrm{OB}-T 1-\mathrm{OC}$ & 110.9 & (10) \\
\hline \multirow[t]{3}{*}{ Mean } & 1.632 & & & $\mathrm{OB}-T 1-\mathrm{OD}$ & 111.1 & (9) \\
\hline & & & & $\mathrm{OC}-T 1-\mathrm{OD}$ & 108.9 & (9) \\
\hline & & & & Mean & 109.5 & \\
\hline$T 2-\mathrm{OA} 2$ & 1.636 & (9) & & $\mathrm{OA} 2-T 2-\mathrm{OB}$ & 110.4 & (10) \\
\hline$-\mathrm{OB}$ & 1.626 & (17) & & $\mathrm{OA} 2-T 2-\mathrm{OC}$ & 105.7 & (10) \\
\hline$-\mathrm{OC}$ & 1.675 & (19) & & $\mathrm{OA} 2-T 2-\mathrm{OD}$ & 109.3 & (9) \\
\hline$-\mathrm{OD}$ & 1.641 & (19) & & $\mathrm{OB}-T 2-\mathrm{OC}$ & 108.2 & (8) \\
\hline \multirow[t]{3}{*}{ Mean } & 1.645 & & & $\mathrm{OB}-T 2-\mathrm{OD}$ & 111.9 & (8) \\
\hline & & & & $\mathrm{OC}-T 2-\mathrm{OD}$ & 111.1 & (8) \\
\hline & & & & Mean & 109.4 & \\
\hline $\mathrm{Rb}-\mathrm{OA} 1 \times 2$ & 3.106 & (17) & 0.204 & & & \\
\hline$-\mathrm{OA} 2$ & 2.974 & (21) & 0.146 & & & \\
\hline$-\mathrm{OB} \times 2$ & 3.168 & (18) & 0.174 & & & \\
\hline$-\mathrm{OC} \times 2$ & 3.140 & (18) & 0.186 & & & \\
\hline$-\mathrm{OD} \times 2$ & 3.049 & (15) & 0.240 & & & \\
\hline Mean & 3.100 & $\Sigma$ & 0.950 & & & \\
\hline
\end{tabular}

* Brown and Altermatt (1985)

Rb-feldspar (Gasperin, 1971). Rubidium-oxygen distances are slightly larger than those reported by Gasperin (1971), but no basic difference in topology has arisen between the two Rb-feldspars. The bond valence sum for the present $\mathrm{Rb}$ cation coordinated by nine $\mathrm{O}$ atoms is $0.950 \mathrm{bv}$, which is close to the $\Sigma$ bv of 0.995 for previous $\mathrm{Rb}$ feldspars (Gasperin, 1971). The lower bond valence sum than found in previous works may be consistent with the lower Rb contents, 'excess$\mathrm{Si}$ ' and $\mathrm{H}_{2} \mathrm{O}$ molecules observed by EMPA and IR methods.

In nature, $\mathrm{Rb}$-rich feldspars with the $(\mathrm{Al}, \mathrm{Si})$ ordered distribution are known as rubicline, analogous to microcline (Teertstra et al., 1998b, 1999a). In the present Rb-feldspar, the mean $T 1-\mathrm{O}$ and $T 2-\mathrm{O}$ distances exhibit a highly disordered (Al,Si) distribution (Table 4). The $(\mathrm{Al}, \mathrm{Si})$ distributions of the present $\mathrm{Rb}$-feldspar calculated from $T-\mathrm{O}$ bond lengths (Kroll and Ribbe, 1983), namely $\mathrm{Al} / \mathrm{Si}=0.245 / 0.755(T 1$ site) and $\mathrm{Al} / \mathrm{Si}=0.255 / 0.745$ ( $T 2$ site), are similar in the ordering degree to those of the Rb-feldspar refined previously (Gasperin, 1971); $\mathrm{Al} / \mathrm{Si}=$ $0.251 / 0.749$ ( $T 1$ site $), \mathrm{Al} / \mathrm{Si}=0.249 / 0.751(T 2$ site). However, there are significant differences in the cell parameters between the Rb-feldspar in the present work and that of Gasperin (Table 5). The cell parameters of our Rb-feldspar are entirely consistent with those reported by other recent studies (Voncken et al., 1993; Koval'skii et al., 2000). The differences between their chemical compositions may provide an explanation for the dissimilarity in cell parameters.

\section{Geochemical implications}

Most minerals in the Earth's upper mantle contain small amounts of structurally bound $\mathrm{H}$. The $\mathrm{OH}$ concentration in each mineral species is variable, in some cases reflecting the geological environment of mineral formation (Bell and Rossman, 1992). Reported analyses of feldspars in nature often include $\mathrm{H}_{2} \mathrm{O}$ molecules or $\left(\mathrm{H}_{3} \mathrm{O}\right)^{+}$ions entering the $M$ site in the feldspar structure (Smith, 1983). In particular, large cations such as $\mathrm{K}, \mathrm{Rb}, \mathrm{Sr}$, Cs and $\mathrm{Ba}$ are frequently contained in feldspar structures capable of accompanying $\mathrm{H}_{2} \mathrm{O}$ molecules (Hofmeister and Rossman, 1985; Beran, 1986; Teertstra et al., 1998a,b,c). The large non-tetrahedral site, normally occupied by $\mathrm{K}$ for sanidine, is well-suited to the site which probably holds the water (Beran, 1986). The incorporation of $\mathrm{H}_{2} \mathrm{O}$ molecules into $\mathrm{Rb}$-feldspar is ascribed to the $\square \mathrm{Si}_{4} \mathrm{O}_{8}$ substitution, because of the generation of a large vacancy in the $M$-site.

The early data suggesting that substitution of $\mathrm{Rb}$ for $\mathrm{K}$ restricts the degree of $(\mathrm{Al}, \mathrm{Si})$ ordering 


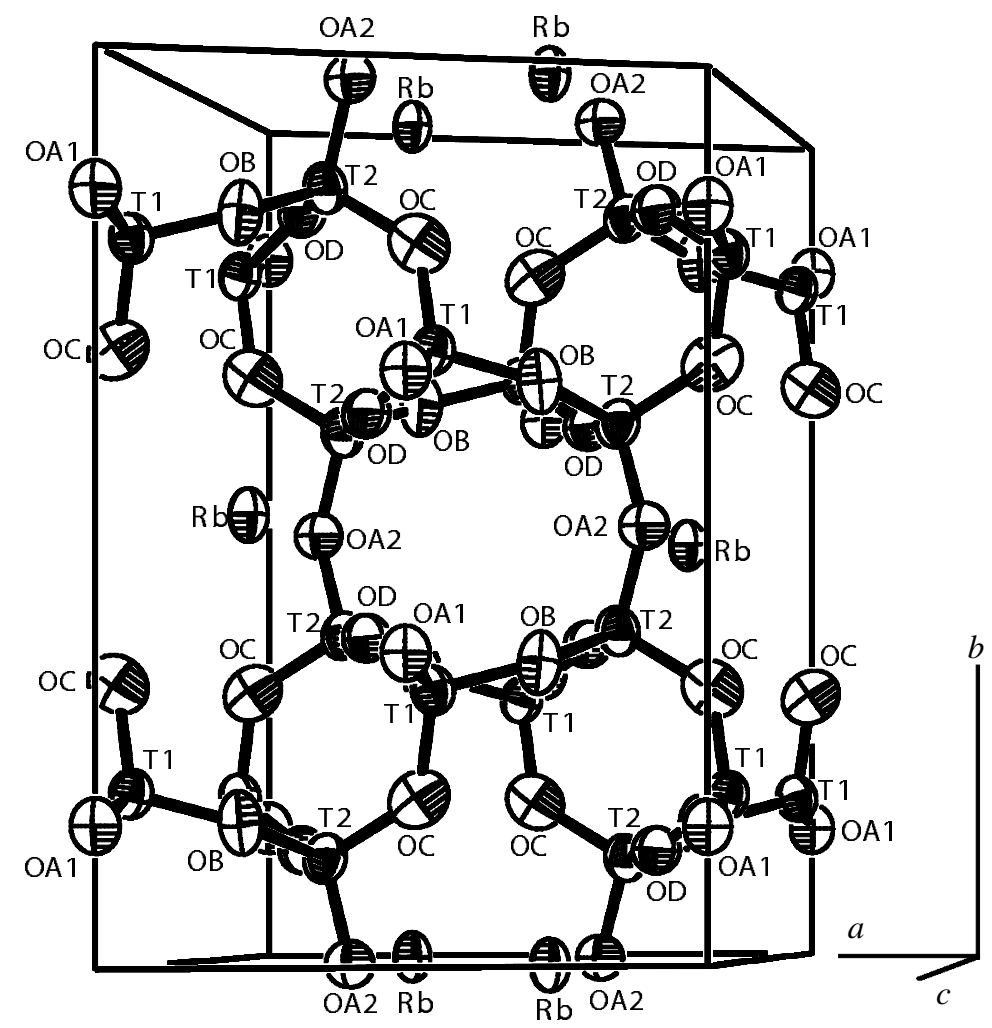

FIG. 4. ORTEP representation of the Rb-feldspar structure viewed approximately down the direction normal to (001), showing probability ellipsoids of thermal vibration. Solid lines are tetrahedral bond directions associated with the framework; the bonding of $\mathrm{Rb}$ to the framework is not shown.

from sanidine to microcline was reaffirmed by Afonina et al., (1979). Smith (1983) suggested that although most of the K-feldspars with high
$\mathrm{Ba}, \mathrm{Rb}$ and $\mathrm{Cs}$ are not fully ordered, a few are strongly ordered, perhaps because of late-stage processes. The present $\mathrm{RbAlSi}_{3} \mathrm{O}_{8}$ feldspar with

TABLE 5. Unit-cell parameters of the synthetic $\mathrm{Rb}$-feldspar in comparison with other $\mathrm{Rb}$-feldspars.

\begin{tabular}{lllllr}
\hline$a(\AA)$ & $b(\AA)$ & $c(\AA)$ & $\beta\left({ }^{\circ}\right)$ & $V\left(\AA^{3}\right)$ & Reference \\
\hline $8.839(2)$ & $13.035(2)$ & $7.175(2)$ & $116.11(1)$ & $742.3(3)$ & 1 \\
$8.837(2)$ & $13.035(3)$ & $7.187(1)$ & $116.27(1)$ & $742.4(2)$ & 2 \\
$8.841(1)$ & $13.036(1)$ & $7.195(1)$ & $116.208(8)$ & $743.5(3)$ & 3 \\
$8.839(1)$ & $13.034(1)$ & $7.182(1)$ & $116.29(1)$ & $741.8(2)$ & 4 \\
$8.834(4)$ & $13.042(5)$ & $7.195(3)$ & $116.42(3)$ & $742.38(1)$ & 5 \\
8.820 & 12.992 & 7.161 & 116.24 & 736.0 & 6 \\
8.844 & 13.044 & 7.190 & 116.35 & 743.3 & 7 \\
8.842 & 13.043 & 7.189 & 116.32 & 743.2 & 7
\end{tabular}

1: this study; 2: Voncken et al. (1993); 3: Koval'skii et al. (2000); 4: Bruno and Pentinghaus (1974);

5: Ghelis and Gasperin (1970); 6: Gasperin (1971); 7: Henderson (1978) 


\section{A. KYONO AND M. KIMATA}

the $(\mathrm{Al}, \mathrm{Si})$ disordered distribution has been synthesized hydrothermally from the low albite with the $(\mathrm{Al}, \mathrm{Si})$ ordered distribution, Meanwhile, the original view has been put forward that diffusion of $\mathrm{Rb}^{+}$and nucleation in the $\square \mathrm{Si}_{4} \mathrm{O}_{8}$ rich microcline leads to formation of rubicline with the $(\mathrm{Al}, \mathrm{Si})$ ordered distribution in the granitic pegmatite (Teertstra et al., 1998b). Therefore it is unclear from the results above how $\mathrm{Rb}$ can retard the ordering process in the feldspar framework (Smith, 1983; Teertstra et al., 1998b).

This study has two geochemical implications: (1) synthetic and natural feldspars composed of the larger $M$-cations tend to incorporate the water, $\square \mathrm{Si}_{4} \mathrm{O}_{8}$ end-members and excess $\mathrm{Al}$; and (2) confirmation of synthetic $\mathrm{RbAlSi}_{3} \mathrm{O}_{8}$ with $(\mathrm{Al}, \mathrm{Si})$ disordered distribution and discovery of $(\mathrm{Al}, \mathrm{Si})$ ordered rubicline in nature mean that both the $(\mathrm{Al}, \mathrm{Si})$ ordered and disordered frameworks of feldspars can accommodate the Rb cation.

\section{Acknowledgements}

The authors are grateful to D.K. Teertstra, University of Manitoba for kindly providing the standard $\mathrm{Rb}$ for electron microprobe analysis. The EMP analyses and crystal data collection were kindly preformed by N. Nishida, at the Chemical Analysis Center, University of Tsukuba. Reviews by P. Benna and M. Schindler led to significant improvement of the manuscript.

\section{References}

Afonina, G.G., Makagon, V.M., Shmakin, B.M., Glebov, M.P. and Makrygin, A.I. (1979) Effects of rubidium and cesium on the structural states of potash feldspars from rare-metal pegmatites. Int. Geol. Rev., 21, 597-604.

Ballirano, P., Maras, A. and Buseck, P.R (1996) Crystal chemistry and IR spectroscopy of $\mathrm{Cl}$ - and $\mathrm{SO}_{4}$ bearing cancrinite-like minerals. Amer. Mineral., 81, 1003-12.

Barrer, R.M. and McCallum, N. (1953) Hydrothermal chemistry of silicates. Part IV. rubidium and cesium aluminosilicate. J. Chem. Soc., 4029-35.

Bell, D.R. and Rossman, G.R. (1992) Water in Earth's mantle: the role of nominally anhydrous minerals. Science, 255, 1391-6.

Beran, A. (1986) A model of water allocation in alkali feldspar, derived from infrared-spectroscopic investigation. Phys. Chem. Miner., 13, 306-10.

Brown, I.D. and Altermatt, D. (1985) Bond-valence parameters obtained from a systematic analysis of the inorganic crystal structure database. Acta Crystallogr., B41, 244-7.

Bruno, E. and Pentinghaus, H. (1974) Substitutions of cations in natural and synthetic feldspars. Pp. 574-610 in: The Feldspars (W.S. Mackenzie and J. Zussmann, editors). Proceedings of NATO-ASI, Manchester, 1972. Manchester University Press, UK. Enraf-Nonius (1983) Structure determination package $(S D P)$. Enraf-Nonius, Delft, The Netherlands.

Gasperin, M. (1971) Structure cristalline de $\mathrm{RbAlSi}_{3} \mathrm{O}_{8}$. Acta Crystallogr., B27, 854-5.

Ghélis, M. and Gasperin, M. (1970) Evolution des paramètres dans le système $\mathrm{KalSi}_{3} \mathrm{O}_{8}-\mathrm{RbAlSi}_{3} \mathrm{O}_{8}$. Compt. Rendu. Acad. Sci., 271, D1928-9.

Grove, T. and Ito, J. (1973) High temperature displacive transformations in synthetic feldspar. Trans. Amer. Geophys. Union, 54, 499.

Grundy, H.D. and Ito, J. (1974) The refinement of the crystal structure of a synthetic non-stoichiometric $\mathrm{Sr}$ feldspar. Amer. Mineral., 59, 1319-26.

Henderson, C.M.B. (1978) Thermal expansion of alkali feldspars. II. Rb-sanidine and maximum microcline. Progress Exp. Petrol. 4th Congr. Rep. Nat. Environ. Res. Council. 4, 51-4.

Hofmeister, A.M. and Rossman, G.R. (1985) A model for the irradiative coloration of smoky feldspar and the inhibiting influence of water. Phys. Chem. Miner., 12, 324-32.

Kimata, M., Nishida, N., Shimizu, M., Saito, S., Matsui, T. and Arakawa, Y. (1995) Anorthite megacrysts from island arc basalts. Mineral. Mag., 59, 1-14.

Kohn, S.C., Henderson, C.M.B. and Dupree, R. (1994) NMR studies of leucite analogues $\mathrm{X}_{2} \mathrm{YSi}_{5} \mathrm{O}_{12}$, where $\mathrm{X}=\mathrm{K}, \mathrm{Rb}, \mathrm{Cs} ; \mathrm{Y}=\mathrm{Mg}, \mathrm{Zn}, \mathrm{Cd}$. Phys. Chem. Miner., 21, 176-90.

Koval'skii, A.M., Kotel'nikov, A.R., Bychkov, A.M., Chichagov, A.V. and Samokhvalova, O.L. (2000) Synthesis and X-ray diffraction study of $(\mathrm{K}, \mathrm{Rb})$ feldspar solid solution: preliminary data. Geochem. Int., 38, 220-4.

Kroll, H. and Ribbe, P.H. (1983) Lattice parameters, composition and $\mathrm{Al}, \mathrm{Si}$ order in alkali feldspars. Pp. 57-99 in: Feldspar Mineralogy, 2nd ed. Reviews in Mineralogy, 2. Mineralogical Society of America, Washington, D.C.

McMillan, P.F., Brown, W.F. and Openshaw, R.E. (1980) The unit-cell parameters of an ordered K-Rb alkali feldspar series. Amer. Mineral., 65, 458-68.

Paulus, H. and Müller, G. (1988) The crystal structure of a hydrogen-feldspar. Neues Jahrb. Miner. Mh., 481-90.

Pentinghaus, H. and Bambauer, H. (1971) Substitution of $\mathrm{Al}(\mathrm{III}), \mathrm{Ga}(\mathrm{III}), \mathrm{Fe}(\mathrm{III}), \mathrm{Si}(\mathrm{IV})$ and $\mathrm{Ge}(\mathrm{IV})$ in synthetic alkali feldspars. Neues Jahrb. Mineral. Mh., 417-8.

Smith, J.V. (1983) Feldspar Minerals, 2. Chemical and 


\section{CRYSTAL STRUCTURE OF NON-STOICHIOMETRIC RB-FELDSPAR}

Textural Properties, 2nd ed. Springer-Verlag, Berlin. Smith, J.V. and Brown, W.L. (1988) Feldspar Minerals,

1. Crystal Structures, Physical, Chemical and Microtextural Properties, 2nd ed. Springer-Verlag, Berlin.

Teertstra, D.K., Černý, P. and Hawthorne, F.C. (1997) Rubidium-rich feldspars in a granitic pegmatite from the Kola peninsula, Russia. Canad. Mineral., 35, 1277-81.

Teertstra, D.K., Černý, P. and Hawthorne, F.C. (1998a) Rubidium feldspars in granitic pegmatites. Canad. Mineral., 36, 483-96.

Teertstra, D.K., Černý, P. Hawthorne, F.C., Pier, J., Wang, L.M. and Ewing, R.C. (1998b) Rubicline, a new feldspar from San Pietro in Campo, Elba, Italy. Amer. Mineral., 83, 1335-9.

Teertstra, D.K., Hawthorne, F.C. and Černý, P. (1998c) Identification of normal and anomalous compositions of minerals by electron-microprobe analysis: K-rich feldspar as a case study. Canad. Mineral., 36, 87-95.

Teertstra, D.K., Černý, P. and Hawthorne, F.C. (1999a)
Geochemistry and petrology of late $\mathrm{K}$ - and $\mathrm{Rb}$ feldspars in Rubellite pegmatite, Lilypad lakes, NW Ontario. Mineral. Petrol., 65, 237-47.

Teertstra, D.K., Černý, P. and Hawthorne, F.C. (1999b) Subsolidus rubidium-dominant feldspar from the Morrua pegmatite, Mozambique: paragenesis and composition. Mineral. Mag., 63, 313-20.

Voncken, J.H.L., Konings, R.J.M., Van der Eerden, A.M.J., Jansen, J.B.H., Schuiling, R.D and Woensdregt, C.F. (1993) Crystal morphology and $\mathrm{X}$-ray powder diffraction of the $\mathrm{Rb}$-analogue of high sanidine, $\mathrm{RbAlSi}_{3} \mathrm{O}_{8}$. Neues Jahrb. Mineral. Mh., $10-16$.

Wietze, R. and Wiswanathan, K. (1971) Rubidiumplagioklas durch kationenaustauch. Fortschr. Mineral., 49, 63.

Wilkinson, R.W.T. and Sabine, W. (1973) Water content of some nominally anhydrous silicates. Amer. Mineral., 58, 508-16.

[Manuscript received 23 January 2001:

revised 30 April 2001] 